Abstracta Iranica Abstracta Iranica

Revue bibliographique pour le domaine irano-aryen

Volume 23 | 2002

Comptes rendus des publications de $\mathbf{2 0 0 0}$

\title{
« The Earliest Persians in Southwestern Iran: The Textual Evidence », Iranian Studies, 32, 1 (1999), pp. 99-107.
}

Rémy Boucharlat

\section{(2) OpenEdition}

1 Journals

Édition électronique

URL : http://journals.openedition.org/abstractairanica/35242

DOI : $10.4000 /$ abstractairanica.35242

ISSN : 1961-960X

Éditeur :

CNRS (UMR 7528 Mondes iraniens et indiens), Éditions de l'IFRI

\section{Édition imprimée}

Date de publication : 15 mai 2002

ISSN : 0240-8910

Référence électronique

Rémy Boucharlat, « «The Earliest Persians in Southwestern Iran: The Textual Evidence », Iranian Studies, 32, 1 (1999), pp. 99-107. », Abstracta Iranica [En ligne], Volume 23 | 2002, document 58, mis en ligne le 08 février 2010, consulté le 25 septembre 2020. URL : http://journals.openedition.org/ abstractairanica/35242 ; DOI : https://doi.org/10.4000/abstractairanica.35242

Ce document a été généré automatiquement le 25 septembre 2020.

Tous droits réservés 
«The Earliest Persians in Southwestern Iran: The Textual Evidence ", Iranian Studies, 32, 1 (1999), pp. 99-107.

\author{
Rémy Boucharlat
}

Utile résumé bien documenté de la documentation écrite (néo-babylonienne, assyrienne et élamite) entre le $9^{e}$ et le $6^{e} s$. av.n.è. sur Parsumaš et le royaume perse du Fars. Certaines questions très débattues, comme la localisation de ces entités, la généalogie des premiers rois perses, la chronologie (voir récemment R. Rollinger Abs. Ir. $\left.22, n^{\circ} 160-161\right)$ sont peu abordées : le panorama assez consensuel que dresse l'A. se veut d'abord clair ; il y réussit.

\title{
INDEX
}

Thèmes : 3.2.2. Pré-Achéménides et Achéménides

\section{AUTEURS}

RÉMY BOUCHARLAT

CNRS - Lyon 